IZA DP No. 10307

Reforming the Integration of Refugees:

The Swedish Experience

Pernilla Andersson Joona

Alma Wennemo Lanninger

Marianne Sundström

October 2016 


\title{
Reforming the Integration of Refugees: The Swedish Experience
}

\author{
Pernilla Andersson Joona \\ SOFI, Stockholm University \\ and IZA
}
Alma Wennemo Lanninger
SOFI, Stockholm University

\author{
Marianne Sundström \\ SOFI, Stockholm University
}

\section{Discussion Paper No. 10307 \\ October 2016}

\author{
IZA \\ P.O. Box 7240 \\ 53072 Bonn \\ Germany \\ Phone: +49-228-3894-0 \\ Fax: +49-228-3894-180 \\ E-mail: iza@iza.org
}

\begin{abstract}
Any opinions expressed here are those of the author(s) and not those of IZA. Research published in this series may include views on policy, but the institute itself takes no institutional policy positions. The IZA research network is committed to the IZA Guiding Principles of Research Integrity.

The Institute for the Study of Labor (IZA) in Bonn is a local and virtual international research center and a place of communication between science, politics and business. IZA is an independent nonprofit organization supported by Deutsche Post Foundation. The center is associated with the University of Bonn and offers a stimulating research environment through its international network, workshops and conferences, data service, project support, research visits and doctoral program. IZA engages in (i) original and internationally competitive research in all fields of labor economics, (ii) development of policy concepts, and (iii) dissemination of research results and concepts to the interested public.
\end{abstract}

IZA Discussion Papers often represent preliminary work and are circulated to encourage discussion. Citation of such a paper should account for its provisional character. A revised version may be available directly from the author. 


\section{ABSTRACT \\ Reforming the Integration of Refugees: The Swedish Experience}

In this paper we evaluate the Swedish Establishment Reform, carried out in 2010 with the goal of speeding up the establishment of refugees and their family. From December 1, 2010 the reform transferred the responsibility for the integration of newly-arrived refugees from the municipalities to the government funded Public Employment Service through which those eligible should get establishment talks, individual plans and coaches. The Reform was motivated by concern over the low employment level and slow integration of refugees. Our approach is to compare the outcomes of the Treatment group, which took part in establishment activities and arrived between December 1, 2010 and December 31, 2011, to those of the Comparison group, which arrived in the eleven months preceding the Reform and participated in municipal introduction programs, controlling for a rich set of observables, including country of birth and month of residence permit. Outcomes are measured in terms of employment and earnings in 2012, 2013 and 2014 for the Treatment group and in 2011, 2012 and 2013 for the Comparison group. Our data comes from registers held by Statistics Sweden and covers all immigrants. The results suggest positive and significant effects of the Reform. In the second year after program-start the Treatment group had about 5.7 percent higher probability of employment and in the third year about 7.5 percent higher. The effects on earnings were larger, about 20 percent higher earnings for the Treatment group after the second year and about 22 percent higher after the third year.

JEL Classification: J15, J61, J68

Keywords: integration, refugees, labor market policy, treatment effect, employment, earnings, caseworkers

Corresponding author:

Pernilla Andersson Joona

Swedish Institute for Social Research (SOFI)

Stockholm University

Universitetsvägen 10F

S-106 91 Stockholm

Sweden

E-mail: Pernilla.Andersson.Joona@sofi.su.se 


\section{Introduction}

In recent years Sweden has received an increasing number of asylum seekers, which makes the extent to which labor market policies can facilitate their integration an interesting and urgent issue. In this paper we evaluate a recent Swedish reform, the Establishment reform, aimed at promoting the establishment of those newly arrived into the labor market using register data on all refugees and their next of kin.

In relation to the number of inhabitants Sweden has received most asylum seekers in the European Union and only Germany has received a higher number of refugees. For quite long it has, however, been clear that Sweden is not doing well when it comes to integrating new immigrants into the labor market. Thus, the integration process has been seen as much too slow since, for example, asylum seekers who got their residence permits in $1997-1999$ had about 25 percentage-points lower employment rates twelve years later than natives of the same gender and age (Statistics Sweden, 2014). Comparing with natives may, however, be misleading since Sweden has higher employment rates than most EU-countries, especially among women. In fact, foreign born persons in Sweden had higher employment rates, on average, in 2012 - 2013 than those in the other EUcountries, especially for women (OECD, 2015). Nevertheless, it is clear that foreign-born persons face greater difficulties in the labor market than natives since, for example, in the fourth quarter of 2015 the unemployment rate for natives was 5.1 percent but 15.9 percent for those born abroad, among which 28.9 percent for those born in Africa and 23.3 percent for those born in Asia (The Swedish Labor Force Surveys). In addition, it is well known that among the foreign-born, refugees have the lowest employment rates (Joyce, 2015). Thus, designing and implementing appropriate policies for promoting the integration of refugees and their next of kin has been crucial.

With this aim, the former Swedish government enacted the so-called Establishment reform in 2010, which transferred the responsibility for the integration of newly arrived refugees from the municipalities to the central government, that is, the Public Employment Service (PES). According to the new law (\#2010:197), from December 1, 2010 all recently arrived refugees and their next of kin 
should register with their local PES to get Establishment talks, Establishment plans, coaches and Establishment benefits. The reform targets new immigrants $20-64$ years, who have been granted residence permits for refugee reasons or for family reunion with a refugee (if they arrived within two years after that refugee), and who are not ill, in school full time or work full time. ${ }^{1}$ The reform aimed, in particular, at promoting the integration of women, since refugee women had been found to participate less in labor-market programs and to have lower employment rates than refugee men (see, for example, Andersson Joona and Nekby, 2012).

The purpose of this paper is to analyze the effects of the reform on employment and earnings from the first to third year after the refugees were enrolled in the program. The approach we take is to compare the outcomes of a Treatment group to those of a Comparison group. We define the Treatment group as those who got their residence permits between December 1, 2010 and December 31, 2011, took part in Establishment activities and received Establishment benefits, 6,410 persons, and the Comparison group as those who got their residence permits in the eleven months preceding the reform, participated in municipal Introduction programs and received introduction benefits, 6,472 persons. We do so because one can reasonably argue that the counterfactual to the reform is the continuation of the municipal programs. We control for a rich set of observables, such as age, gender, education, country of birth, refugee category, year and quarter of residence permit, unemployment in the municipality the outcome year and county of residence the outcome year. We perform two types of multivariate analyses: First, we do yearly comparisons of outcomes in each of the years 2012, 2013 and 2014, respectively, for the Treatment group with those of the Comparison group one year earlier, that is, in 2011, 2012 and 2013, respectively. Second, we estimate the changes over the three years separately for the Treatment and Comparison group. In addition, we perform a couple of sensitivity analyses to test the robustness of our findings.

\footnotetext{
${ }^{1}$ The reform also targets refugees 18 - 19 years old that do not have parents in Sweden but they are not included in our study since we measure outcomes in terms of employment, earnings and regular education. Also, they are very few.
} 
The paper is organized as follows: In the next section we describe the Establishment reform, its aim and implications, as well as the pervious system of introduction. In the following section we review previous studies of integration measures. We then turn to our data, method and variables. Section 5 presents our findings and Section 6 concludes.

\section{The Establishment Reform}

\subsection{Aim and background}

The aim of the Reform was to change the program for introduction of certain newly-arrived immigrants in order to facilitate and speed-up their integration into the labor market and the society (Swedish Government Bill 2009/10:60). Before the Reform there was a large variation across municipalities in the reception of refugees as well as in the organization of introduction measures and in how well they worked (Swedish Board of Integration, 2007), see Section 2.3. The Reform is also likely to have been influenced by the experiences of the other Nordic countries, which had more centralized and more uniform programs, as well as by the findings in previous research that individual integration plans and intensive coaching tended to increase the probability of employment among newly arrived immigrants, see Section 3 for a discussion. Also part of the background, is the fact that the course that countries, such as Germany, has adopted with reduced entry level wages to lower the thresholds into the labor market, is blocked to a high degree in Sweden because of strong opposition from the major trade unions. Instead, policy makers rely heavily on active labor market policies, such as search and matching assistance, intensive coaching and subsidized employment.

\subsection{Implication of the reform}

As mentioned, the new law implied that from December 1, 2010 all newly arrived in the target group should register with the PES. The PES shall offer Establishment talks during which the experience, qualifications and needs of the individual, are clarified as a basis for drawing up an Establishment plan. Each registered person is entitled to such a plan within two months after he/she received his/her residence permit. The plan should cover at most 24 months and include Swedish for immigrants, orientation about Swedish society and measures preparing the participant for work. The 
municipalities are responsible for the classes in Swedish and those about Swedish society, while the other activities in the plan can be performed by the PES or other agents. The PES is also responsible for helping the refugees to find housing if needed. An important part of the reform was to give the participants access to more intensive coaching than the previous system did. Thus, the PES would offer the participants a coach operating on its behalf in order to assist the participants in fulfilling their plan by providing them with advice, contacts and coaching. The participants could choose a coach among several private agents. ${ }^{2}$ Those who have got an Establishment plan and participate in activities are entitled to Establishment benefits and, in certain cases, also housing benefits. In contrast to the previous system, benefits are individual and equal across the country. If the participants work for pay while following a plan, they may, in most cases, keep their benefits and may continue to do so during the whole time with a plan, for at most 24 months, or until they have worked full time for six months or begun tertiary education.

\subsection{The previous system of introduction}

According to the previous legislation, those who had been granted residence permits for refugee related reasons or as next of kin of such a person (if they arrived within two years) should have the right to a place in an Introduction Program in the municipality where they lived. The municipality was reimbursed for the program participation for at most 24 months by the Swedish Migration Board (SMB). For participants of working ages consultations with the local employment services should take place and for all above 16 years of age the program should include Swedish for immigrants, practical work experience and orientation about the Swedish society. The program quality varied, however, across the country. The participants received Introduction benefits or social assistance which were based on household income. The municipalities were free to decide what type of benefits they paid and their level, and if benefits, or part of them, could be kept if the participants had other income. Thus, benefit levels varied across the country (Eriksson 2010, Section 5.2.1).

\footnotetext{
2 The system with private coaches was strongly criticized e.g. by the Swedish National Audit Office (2014a) for not being focused on work and was abolished in February 2015 and replaced by the caseworkers at the PES.
} 


\subsection{Implementation of the Reform}

Follow-ups, such as the Public Employment Service (2013) and the Swedish National Audit Office (2014b) indicate that there were problems in the implementation of the Reform. In many municipalities the newly arrived did not get an Establishment plan within the stipulated two months after the residence permit. Many of the newly arrived also had problems supporting themselves, since participants obtain benefits only after taking part in program activities. A third problem was that many of the refugees - about one-third - were unable to participate in the activities due to poor physical and mental health. A fourth problem is that there has been a shortage of housing for the newly arrived in many municipalities. ${ }^{3}$ Thus, because of the problems that the newly arrived have had with health, economic support and housing, and the limited experience of the caseworkers of dealing with such problems, the reform did initially not work as intended.

\section{Previous studies of introduction measures}

\subsection{Swedish studies}

Previous research on the effects of introduction measures, such as search and matching assistance and intensive coaching, on the integration of newly arrived persons in the Swedish labor market has not found clear positive results, at least not for women. One example of a measure, introduced to promote integration, is the pilot project SIN (Special Introduction) which started in 20 municipalities in 2003 and is evaluated by Johansson and Åslund $(2006,2011)$. At first, the intention was that the PES case workers should take part in the work place introduction, but in practice they mainly worked with search and matching assistance. The experiment led to an increased inflow to work practice, which, in turn, raised the probability of regular employment. There was, however, no direct effect of participating in the SIN-experiment on regular employment.

\footnotetext{
${ }^{3}$ Asylum seekers who are registered at the SMB in principle free to choose where to live if they can find own housing but if they depend on the SMB for housing they have to settle in municipalities that are willing to receive them, often those with vacant apartments, see Section 4.3 for further information.
} 
Further, in 2006 a trial introduction program for newly arrived immigrants was introduced in three counties: Kronoberg, Skåne and Stockholm. ${ }^{4}$ Among the participating municipalities, nine adopted the program as a randomized experiment, in which the PES case workers assigned the newly arrived to the program or the normal activities of the PES by a lottery. Those who participated in the experiment received intensive counseling and coaching from case workers with substantially reduced caseloads compared to other caseworkers. Evaluating the experiment, Andersson Joona and Nekby (2012) found that in the end of the trial period the program participants had about six percentagepoints higher probability of regular employment. This result applied, however, only to men, for women there was no difference between the treatment and the control group.

Related to our study, Liljeberg and Sibbmark (2011) evaluated an experiment with Establishment talks that took place in 2009 - 2010 on the initiative of the government (Swedish Government, 2008). The talks targeted refugees and their next of kin and were organized in collaboration between the SMB and the PES. The evaluation is based on interviews with PES caseworkers and SMB staff as well as register data from PES and Statistics Sweden. The outcomes of the participants in the experiment are descriptively compared to a comparison group of similar refugees registered at the PES but not taking part in the Establishment talks. ${ }^{5}$ Initially the experiment was carried out in four cities, Göteborg, Skellefteå, Karlskrona and Kristianstad, but from March 2010 it was extended to about twenty more places all over the country. Outcomes are examined in the end of 2009 for the four initial cities and in the end of 2010 for all who took part in talks or were in the comparison group in the extended experiment until April 2010, all in all about 2000 persons who had Establishment talks. The results show that refugees who had Establishment talks, on average, met the PES earlier and were sooner enrolled in a labor market program than those who did not have such talks. Very few had left the PES for employment. Since the experiment in practice worked as a

\footnotetext{
${ }^{4}$ The trial program was phased out on June 30, 2008.

${ }^{5}$ The main reason why these refugees did not participate in the Establishment talks was probably that they lived in places where there were no such talks according to the authors.
} 
pilot project for the Establishment reform, it may have influenced our Comparison group positively, thereby downward biasing our results.

Thus, previous findings suggest that measures which are closely linked to the labor market and to a high degree resemble regular employment increase the probability of finding work for new immigrants. It has also been found that intensive coaching has a positive impact on job chances, at least for men. These findings are likely to have influenced the changes in the integration policy that was carried out by the enactment of Establishment reform.

Finally, in Andersson Joona et al (2015) we evaluated the first year of the reform using the same approach as in this study and similar definitions of the treatment and comparison groups. Outcomes were measured in terms of employment, annual earnings and enrolment in regular education and observed in 2012 for the Treatment group and in 2011 for the Comparison group. But, although there were good reasons to expect some positive effects of the reform, we found none. Possible explanations for this result are the start-up problems of the reform, the pilot experiment with Establishment talks and that too short time had passed for any effect to be observable. Thus, it is interesting to see if we find any effects of the reform after the second and third year.

\subsection{Nordic experiences and studies}

Although Sweden has had a much larger inflow of immigrants than Denmark and Norway in the postwar period, all had labor migration in the 1950s and the 1960s and refugee immigration in the 1980s and, especially, in the 1990s (for a review and comparison with Finland and Iceland, see Korpi, Bäckman and Minas, 2015). After this point, Denmark deviated by restricting the right to asylum and family reunion; restrictions partly motivated by the difficulties of immigrants to find employment. When it comes to integration policies, there are also many similarities. Thus, while the Danish policy has implied reduced benefits and more restricted criteria for receiving benefits, from 2002 Denmark also had a start-help program which included language classes and work oriented training. Thereby, the program resembled the Swedish Introduction Program introduced in 1994, the Finnish introduced in 1999 and the Norwegian introduced in 2003. The programs differed by being 
mandatory for refugees in Denmark, Norway and Finland, but voluntary in Sweden. Another important difference was that the central government in Denmark, but to some extent also those in Norway and Finland, exercised more control over the municipal programs. Denmark had, for example, quite detailed directions regarding the contents of the programs, while in Sweden this was largely not the case. A third difference lay in the use of sanctions, for example, when program participants did not turn up for classes or did not apply for a job referral. Such sanctions were mandatory in the programs of Denmark, Finland and Norway, whereas in Sweden the municipalities were free to decide whether to introduce them or not.

The reform that most resembles the Establishment Reform is, however, the one adopted in Finland in 1999, which introduced "integration plans" for unemployed immigrants. The plans consist of individualized sequences of labor-market programs that a caseworker believes to be appropriate for each immigrant. Sarvimäki and Hämälainen (2016) use a regression discontinuity approach to evaluate the reform. They find that reform increased compliers' cumulative earnings by 47 percent over a ten-year period and attribute this increase to changes in the content of training, rather than to the amount of training.

Korpi et al (2015) compare and analyze trends in employment among natives, immigrants from Western countries and immigrants from non-western countries aged 30 - 59 years in Denmark, Finland, Norway and Sweden over the period 1993 - 2006. Their results suggest that the growth in employment among non-western immigrants has been somewhat higher in Denmark than in the other countries and that this is mainly due to the changes in the integration policy rather than the more restrictive migration policy (p. 98). These findings are consistent with Danish, Finnish and Norwegian evaluations which indicate that measures, such as subsidized employment and language classes, have had positive employment effects, as have, but more limited, the reduced benefit levels in Denmark, see Clausen et al (2009), Huynh et al (2010). Most likely, the experiences of more control from the central government in Denmark and the integration plans in Finland have influenced the previous Swedish government when designing the Establishment Reform. 
4. Data, method and variables

\subsection{Data}

We use an excerpt from the STATIV database of Statistics Sweden covering all individuals who immigrated to Sweden from January 1, 2009 to December 31, 2012 (Statistics Sweden, 2013). The excerpt comprises information on all immigrants collected from registers at Statistics Sweden and the SMB. For our study, Statistics Sweden has supplemented the data with information from the PES.

\subsection{Method}

As mentioned, the approach we take is to compare the outcomes of a Treatment group with those of a Comparison group. We define the Treatment group as those who got their residence permits between December 1, 2010 and December 31, 2011, took part in the Establishment program and received Establishment benefits, 6,410 persons, and the Comparison group as those who got their residence permits in the eleven months preceding the reform, participated in municipal Introduction programs and received Introduction benefits, 6,472 persons. We follow the Treatment group from December 1, 2010 through 2014 and the Comparison group from January 1, 2010 through 2013 and perform two sets of multivariate analyses. First, we estimate yearly differences between the groups in which outcomes are measured in 2012, 2013 and 2014, respectively, for the Treatment group, and one year earlier, in 2011, 2012 and 2013, respectively, for the Comparison group.

The model to be estimated can be specified in the following way:

$$
Y_{i t}=\alpha_{0}+\gamma R E F O R M_{i}+\delta T I M E_{i}+6^{\prime} X+\varepsilon_{i}
$$

where $Y_{i t}$ is the outcome for individual $i$ : Employment and earnings, respectively, $t$ is equal to 2012, 2013 and 2014, respectively, if the individual belongs to the Treatment group and equal to 2011, 2012 and 2013, respectively, if the individual belongs to the Comparison group. ${ }^{6}$ REFORM is equal to one for the Treatment group, and equal to zero for the Comparison group, and $\gamma$ is the parameter of interest. TIME is measured by a set of dummy variables which are equal to one for the year and

\footnotetext{
${ }^{6}$ For enrollment in regular education we do no multivariat analyses but present frequencies in Table 2.
} 
quarter of the year the individual received his/her residence permit and equal to zero for other time periods. $B^{\prime} X$ is a vector of control variables and $\varepsilon$ is the random error.

Second, we estimate the changes in outcomes over the three years separately for the Treatment and Comparison groups. This model can be written:

$$
Y_{i k t}=\alpha_{0}+b^{\prime} X_{i k t}+\delta Y_{e a r_{k t}}+\varepsilon_{i}
$$

where $Y_{i k t}$ is the outcome for individual $i$ : Employment and earnings, respectively, $k$ denotes whether the individual belongs to the Treatment group or the Comparison group, $t$ is equal to 2012, 2013 and 2014 for the Treatment group and equal to 2011, 2012 and 2013 for the Comparison group, b $^{\prime} X_{i k t}$ is a vector of similar control variables as in model (1) and Year $_{k t}$ is a set of dummy-variables which are equal to one for each year for each group and otherwise equal to zero. The first year is the reference category for each group. The parameters of interest are the four $\delta$.

For identification, the approach relies on the assumption that there are no unobserved characteristics of any of the groups that are correlated with outcomes. We can, of course, not know whether this is the case or not, but perform a couple of robustness checks to test the plausibility of the assumption, see Section 5.3.

\subsection{Variables}

\subsubsection{Control variables}

Since the composition of our two groups may differ and since outcomes are measured in different years for the two groups, control variables are important for our approach to be valid. Besides gender and age, our control variables are country of birth, educational attainment, refugee category, month of residence permit, days of national registration, married, children 0 - 6 years, county of residence and local unemployment rate. Country of birth is divided into Afghanistan, Eritrea, Europe, Iraq, Iran, Somalia, other African country, other Asian country, other Middle-East country and other regions. ${ }^{7}$ Educational attainment is grouped into the levels Primary Education less than nine years,

\footnotetext{
${ }^{7}$ This classification distinguishes the major countries of origin and is as detailed as available in the data.
} 
Lower Secondary, Upper Secondary, Post-Secondary Education and Unknown education. Refugee category is grouped into the following categories: Quota Refugee, SMB Housing, Own Housing and Family Reunion. Own housing and SMB Housing refer to the housing refugees who sought asylum via the SMB had during the asylum process; those with own housing had found housing by themselves, mainly living as lodgers with relatives and friends, while those who could not find housing got SMB Housing in municipalities that were willing to receive them (see note 3). Quota refugees have residence permits before entering Sweden and those who have been granted the right to reunion with a family member already have housing.

Days of national registration is a continuous variable measured in days in the end of each outcome year. Married is equal to one for married persons and zero for other persons. Children 0 - 6 years is equal to one for those with children under 7 in the household and zero for other persons. County of residence is measured by a set of dummy variables equal to one for the county the individual lived in the year outcome is measured, and zero for other counties. Local unemployment rate is the unemployment rate according to PES in the municipality the individual lived in the year outcome is measured.

Descriptive statistics for the two groups is presented in Table 1. We see that the groups are rather similar in gender and age composition, refugee category and county of residence, but differ noticeable in educational level and country of birth. As expected, both groups have low levels of education and while the fractions with less than nine years of schooling and upper-secondary education are higher in the Treatment group, the fraction with unknown or missing education is higher in the Comparison group. Most likely, this is because the Treatment group has got help from the PES to validate their education through the Establishment talk and the PES, in turn, has included the information in the data base. Further, we see that the fraction born in Somalia is almost twice as large in the Comparison group, while the fractions born in Afghanistan, Eritrea and Iraq are larger in the Treatment group. Finally, we observe that both groups of newly arrived immigrants live in 
municipalities where the unemployment rate is higher than the national average which was 6.3 percent in 2014 and 6.7 percent in 2013.

For women the frequencies are very similar to those for both sexes except for two variables. First, the fraction of family reunion cases is higher among women, and, second, the fraction with less than nine years schooling is higher among women. In the Comparison group the fraction with unknown education is higher among women.

\subsubsection{Outcome variables}

As mentioned, outcomes are measured in terms of employment and annual earnings, and observed in 2012 - 2014 for the Treatment group and in 2011 - 2013 for the Comparison group. In particular, the variable employed is equal to one if the individual was employed in November, as recorded by Statistics Sweden, or if the individual was employed sometime during the year according to an income report from an employer to the tax authorities, and zero otherwise. We have no information on how much the individual worked. Annual earnings is the total gross wage income received during the year and measured in in 2014 prices. We define student as equal to one if the individual was enrolled in regular education other than upper-secondary school or Swedish for immigrants during the year, and zero otherwise.

We present means and frequencies for our outcome variables, as well as for enrolment in regular education and participation in labor market training, for the two groups in Table 2. We see that that the fraction employed sometime during the year increases over time for both groups, but more for the Treatment group. The fraction that had any earnings is, as expected, very similar to the fraction employed. The median earnings are rather low but rise over the three years for both groups, especially for the Treatment group. As this measure only includes wages, and no sick pay or parental leave benefits, this suggests that the participants in the Establishment program have worked more days and hours in their second and third year. Finally, we find that the fraction enrolled in regular education is rather similar and increases from the first year to the second year for both groups. Also, it is clear that the Treatment group has received more labor market training. Thus, the displayed 
means and frequencies indicate more favorable outcomes for the Treatment group. It is interesting to see whether these differences remain after the multivariate analysis, which we now turn to, has taken account of differences in background characteristics.

\section{Findings}

\subsection{Differences by year}

Our main findings are summarized in Table 3 (for full models with coefficients for all control variables for both outcomes in 2014 vs. 2013, see Appendix). ${ }^{8}$ Starting with employment, we see that the probability of any employment during the year was significantly higher for the Treatment group in the second and third year after program start, but in the first year there was no difference between the groups. The estimates indicate that the probability of employment was about 1.8 percentagepoints higher for participants in the Establishment program in the second year after the reform and about 2.7 percentage-points higher in the third year after all control variables had been included. In percent this corresponds to about 5.7 percent higher employment rates for the Treatment group in the second year and about 7.5 percent higher employment rates in the third year. ${ }^{9}$ The estimates, thus, suggest a somewhat larger effect in the third year but this difference is not statistically significant. Further, the estimates point to a lower probability of employment for women all three years and about 18 percentage-points lower in the third year (We discuss how the other control variables are correlated with employment below).

When it comes to earnings the results indicate a stronger effect of the reform, about 20 percent higher earnings for the Treatment group after the second year and about 22 percent higher after the third year. ${ }^{10}$ As before, we find no effect after the first year. Our interpretation of this rather strong effect is that the participants in the Establishment program worked more days and

\footnotetext{
${ }^{8}$ The full models for 2013 vs. 2012 have been omitted out of consideration of space but are very similar and can be obtained from the authors on request.

${ }^{9}$ Since 1.8/31.6 $=0.057$ where 1.8 is obtained from Table 3 and 31.6 percent is the fraction employed of the Comparison group according to Table 2 and, similarly, $2.7 / 36.0=0.075$.

${ }^{10}$ Since the estimates are in log units, they have to be recalculated to obtain percent: $\exp (0.184)-1=0.202$ and $\exp (0.202)-1=0.224$.
} 
hours than those in the municipal programs. It is less likely that the Treatment group has got better paid jobs as we have controlled for most relevant background factors and the wage dispersion is small among low educated persons. In addition, we see that women earned considerably less than men all years, between 20 and 51 percent less.

As promoting the integration of women was one goal of the reform, an examination of its effects by gender is called for. We do so by estimating the same models as above for women and men separately. We present the resulting estimates for 2014 compared to 2013 in Table 4 and see that they are very similar. In fact, a statistical test reveals that the estimates for women are not significantly different from those for men, suggesting that the reform has had equally positive effects for women and men. This is in contrast to, for example, the trial experiment evaluated by Andersson Joona and Nekby (2012) which found positive effects only for men.

Before we go on to the analysis of differences over time, let us briefly discuss how other control variables than gender are correlated with the probability of employment in the third year based on the estimates in Model IV; Appendix Table A. Most correlations are in line with our expectation and none of them differ between the Treatment and the Comparison group. ${ }^{11}$ Thus, younger persons have a higher probability of employment, and the presence of pre-school children is negatively correlated with employment, but marital status is not significantly correlated. When it comes to country of birth, individuals from Iraq have lower employment chances than those born in other countries. Unknown education is negatively correlated, as expected, while having at least nine years education is positively correlated. As to refugee category, the results suggest that those who have own housing or SMB Housing more often are employed than the quota refugees and the family union persons. Days of national registration and month of residence do not have a significant association with employment in the full model. As expected, the local unemployment rate is negatively correlated with the probability of employment. When it comes to county of residence, for which we out of considerations of space do not show the coefficients, the results indicate that the

\footnotetext{
${ }^{11}$ We tested this by adding an interaction between Reform and each of the control variables, one at a time, to the full model.
} 
probability of employment are higher in Stockholm County and Norrbotten County. Finally, it is interesting to note that the local unemployment rate and county of residence explains a large share of the variation in probability of employment.

\subsection{Differences over time}

We also estimated the change in employment and earnings over the three years separately for the Treatment group and the Comparison group with similar control variables as in the models above. ${ }^{12}$ The estimates are presented in Table 5 and suggest that outcomes improved over the three years for both groups, but more for the Treatment group. We see that the difference is particularly large for earnings; the Treatment group had significantly higher earnings both in the second and third year and the difference was larger in the third year. The results indicate that in the third year after program start, the participants in the Establishment program had significantly higher probability of employment, about five percentage-points higher, and about 20 percent higher earnings than participants in the municipal programs.

\subsection{Robustness checks}

In order to investigate whether our results are robust, and not due to coincidences or misspecifications, we perform a couple of sensitivity analyses. We start by a so-called placebo test in which we assume that the reform was carried out eleven months earlier, that is, on January 1, 2010, and compare the outcomes of our Comparison group in 2013 with the outcomes in 2012 of the newly arrived who got their residence permits one year earlier, that is, in 2009. Hence, we compare two cohorts of participants in the Introduction programs after three years and include the same control variables as in Model (1) above. ${ }^{13}$ The resulting estimates are displayed in Table 6 together with the estimates from Table 3 and indicate that the placebo reform did not affect employment or earnings,

\footnotetext{
${ }^{12}$ The difference is that when we estimate the differences over time we include a dummy for municipality of residence, instead of local unemployment rate and county of residence, since that gives a higher explanatory power.

${ }^{13}$ With the exception of month of residence permit which not available for the 2009 cohort.
} 
which is as expected and does not suggest that our Comparison group deviates in ways we have not been able to control for.

In the second sensitivity analysis we investigate whether our findings are due to unobserved characteristics of the Treatment group. We do so by comparing the outcomes in 2014 of those who enrolled in the Establishment program in 2012, that is, one year after our Treatment group, with the outcomes of our Treatment group in 2013, that is, after the second year for both cohorts, including the same control variables as in Model (1). The resulting estimates are presented in Table 7. They are in line with our expectation and do not suggest that our main findings reflect unobserved positive characteristics of the Treatment group. The more positive effect on employment for those who enrolled in the program during 2012 is consistent with the start-up problems of the reform discussed in Section 2.4. For earnings we find no difference between the cohorts.

An issue related to that of unobserved characteristics of the Treatment group, is whether the Reform attracted more refugees to Sweden. This unlikely to be the case since the average number of adult asylum seekers per month in the period after the reform, December 1, 2010 to December 31, 2011 was, in fact, lower than in the eleven months preceding it, January 1 to November 30, 2010, 1649 persons as compared to 1802 persons, including those above 65 years according to the SMB. In addition, the average monthly enrolment rate in the Establishment program was lower than that in Introduction program, 493 persons as compared to 588 persons, see Table 1. In our opinion, the refugee flows to Sweden are more influenced by the situation in the home countries of the refugees and, as is clear from the changes since the fall of 2015, by the Swedish migration policy than by the Swedish integration policies.

\section{Conclusions}

In this paper we have analyzed the effects of the Establishment Reform on the employment and earnings of newly-arrived refugees and their next of kin one, two and three years after they got their residence permits. Our approach is to compare the outcomes of a Treatment group to those of a Comparison group, where the Treatment group consists of refugees and their next of kin who got 
their residence permits between December 1, 2010 and December 31, 2011 and participated in the Establishment program. The Comparison group consists of refugees and their next of kin who got their residence permits between January 1 and November 30, 2010 and participated in the preceding municipal Introduction programs. We do so because the reasonable counterfactual to the Reform is the continuation of the municipal programs. We perform both yearly comparisons of the outcomes of the two groups and of the changes in outcomes over the three years separately for each group controlling for a rich set of background variables.

Our findings suggest that the Reform had a small positive and statistically significant effect on the employment of the newly-arrived immigrants in the second and third year after program enrolment, but no effect after the first year. On average, the probability of any employment for the participants in the Establishment program was 1.8 percentage-points higher after two years and 2.7 percentage-points higher after three years than for those in the municipal programs. This corresponds to 5.7 percent higher employment after the second year and 7.5 percent higher after the third year, but the difference between the estimates is not statistically significant. The results further indicate that the local unemployment rate and county of residence are important for the probability of employment for the newly-arrived immigrants, since they explain a large part of the variation in employment.

When it comes to earnings, the results point to larger effects. Employed participants in the Establishment program had, on average, about 20.2 percent higher earnings after two years and about 22.4 percent higher earnings after three years. Our interpretation of this finding is that the reform lead to an increase in days and hours worked.

Further, we find less favorable outcomes for women. Thus, women had between 16 and 18 percentage-points lower probability of employment and between 30 and 40 percent lower earnings, everything else equal. Estimations of Reform effects separately for women and men suggest, however, that the reform had positive effects of the same magnitude for women and men. 
Our estimations of changes over time for the groups show that outcomes improve for both groups, but more for the Treatment group, and especially for earnings. The Treatment group had significantly higher earnings in both the second year and the third year, and significantly higher probability of employment in the third year, about five percentage-points higher. In the third year, their earnings were about 20 percent higher, which is in line with the findings for Finland by Särvimäki and Hämäläinen (2016).

In order to investigate the robustness of our findings, we conducted two sensitivity analyses. First, we performed a placebo test in which we assumed that the reform was introduced eleven months earlier, that is, on January 1, 2010, and compared the outcomes of our Comparison group in 2013 to those in 2012 of the refugees who got their residence permits in 2009 and were enrolled in the municipal programs. The results were in line with our expectation and showed no effect on employment or earnings, suggesting that our Comparison group does not deviate in a way that affects the results. Second, we tested if our findings reflect unobserved characteristics of the Treatment group by comparing the outcomes in 2014 of those who enrolled in the Establishment program one year later, that is, in 2012, to the outcomes in 2013 of our Treatment group. The results point to a small but significant positive effect on employment for the former group but no effect on earnings. These findings are consistent with the Reform having had start-up problems and do not suggest that there are unobserved positive characteristics of our Treatment group.

Finally, let us briefly discuss the possible mechanisms underlying the positive effects of the Reform. Our interpretation is that the Reform has brought the newly-arrived in contact with the PES earlier and that, thereby, the focus on labor-market entry was strengthened. Also, through the Establishment talks, the newly-arrived got the opportunity to clarify and validate their education and previous experience. This talk, further, gave the PES a clearer picture of the individuals' qualifications and needs which were useful when designing appropriate individual Establishment plans, including relevant labor-market training. In addition, the change from benefits based on household income to individual and equal benefits may have contributed to the positive outcomes. 


\section{References}

Andersson Joona, Pernilla and Lena Nekby (2012) Intensive coaching of new immigrants: An evaluation based on random program assignment, Scandinavian Journal of Economics, 114(2):576-600.

Andersson Joona, Pernilla, Lanninger, Alma W. and Marianne Sundström, "Improving the integration of refugees: An early evaluation of a Swedish Reform." Discussion Papers No. 9496, IZA, Bonn, 2015

Åslund, Olof and Per Johansson (2011) Virtues of SIN: Can increased public efforts help Disadvantaged immigrants? Evaluation Review, 35(4):399-427

Clausen, Jens, Heinesen, Eskil, Hummelgaard, Hans, Husted, Leif and Michael Rosholm (2009) The effect of integration policies on the time until regular employment of newly arrived immigrants: Evidence from Denmark, Labour Economics 16:409-417.

Huynh, Duy T., Schultz-Nielsen, Marie Louise and Torben Tranæs (2010) The employment effects upon arrival of reducing welfare to refugees, in M. L. Schultz-Nielsen, Essays in migration and fertility, Ph. d. dissertation, Aarhus School of Business, Aarhus University.

Johansson, Per and Olof Åslund (2006) Arbetsplatsintroduktion för vissa invandrare - teori, praktik och effekter, Rapport 2006:6, Uppsala: IFAU

Joyce, Patrick (2015) Integrationspolitik och arbetsmarknad. Rapport 2015:3, Stockholm: Delmi www.delmi.se

Korpi, Tomas, Bäckman, Olof and Renate Minas (2015) Att möta globaliseringen. Rapport 2015:534, Tema Nord, Nordiska ministerrådet.

Liljeberg, Linus and Kristina Sibbmark (2011) Uppföljning av etableringssamtal. Rapport 2011:28. IFAU, Uppsala.

OECD/European Union (2015) Indicators of immigrant integration 2015: Settling in. OECD Publishing, Paris.

Public Employment Service (2013) Etablering av vissa nyanlända - analys av genomförandet. Avser januari - april 2012, Arbetsförmedlingen.

Sarvimäki, Matti and Kari Hämäläinen (2016) Integrating immigrants: The impact of restructuring active labor market programs, Journal of Labor Economics 34:479-508.

Statistics Sweden (2013) Dokumentation av databasen STATIV, www.scb.se/stativ/.

Statistics Sweden (2014), Integration - etablering på arbetsmarknaden (Integration - establishment on the labor market). Integration. Rapport 7.

Swedish Board of Integration (2007) Ett förlorat år. En studie och analys av insatser och resultat under introduktionens första 12 månader, Integrationsverkets stencilserie 2007:05. 
Swedish Government Bill 2009/10:60, Nyanlända invandrares arbetsmarknadsetablering-egenansvar med professionellt stöd.

http://ec.europa.eu/ewsi/UDRW/images/items/docl 19549 607965119.pdf

Swedish National Audit Office (2014a) Etableringslotsar - fungerar länken mellan individen och arbetsmarknaden? RIR 2014:14, Riksrevisionen.

Swedish National Audit Office (2014b) Att tillvarata och utveckla nyanländas kompetens - Rätt insats i rätt tid? RIR 2014:11, Riksrevisionen. 
Table 1. Means and frequencies for the control variables for the Treatment and Comparison groups. Per cent.

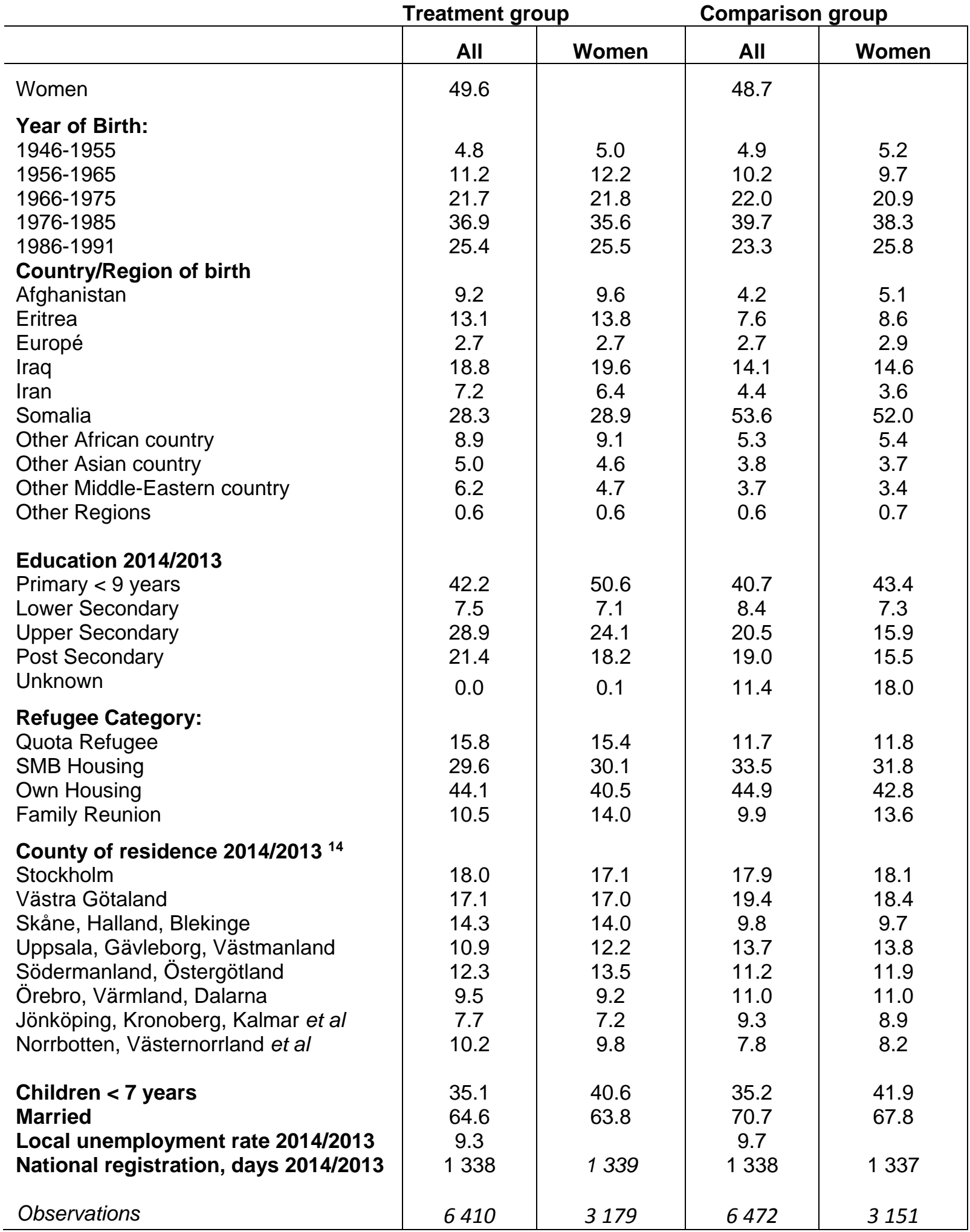

\footnotetext{
${ }^{14}$ County of residence is grouped here for reasons of space, but in the multivariate analysis it is accounted for by a dummy variable for each county.
} 
Table 2. Means and frequencies for the outcomes for the Treatment and Comparison groups. Per cent and EUR.

Treatment group

Comparison group

\begin{tabular}{|c|c|c|c|c|c|c|}
\hline & 2012 & 2013 & 2014 & 2011 & 2012 & 2013 \\
\hline Any employment, \% & 22.7 & 33.6 & 41.7 & 22.0 & 31.6 & 36.0 \\
\hline Had any earnings, $\%$ & 22.5 & 33.3 & 40.8 & 21.9 & 31.2 & 35.3 \\
\hline Annual earnings, median ${ }^{a}$ & 554 & 939 & 1,253 & 524 & 826 & 1,119 \\
\hline Student, \% & 16.1 & 20.2 & 21.1 & 16.7 & 22.7 & 22.4 \\
\hline Labour-market training & 8.6 & 11.7 & 13.7 & 5.2 & 3.2 & 8.1 \\
\hline
\end{tabular}

${ }^{\text {a }}$ Reported in EUR in 2014 prices for those with positive earnings according to the exchange rate in May 2016.

Table 3. Estimated effects of the Establishment Reform on A: the probability of any employment during the year and B. on the logarithm of annual earnings. Both sexes.

\begin{tabular}{lccc|ccc}
\hline & \multicolumn{3}{c}{ A. Employment } & \multicolumn{3}{c}{ B. Earnings } \\
& 2012 vs. & 2013 vs. & 2014 vs. & 2012 vs. & 2013 vs. & 2014 vs. \\
& 2011 & 2012 & 2013 & 2011 & 2012 & 2013 \\
\hline Reform & 0.001 & $0.018^{* *}$ & $0.027^{* * *}$ & 0.021 & $0.184^{* * *}$ & $0.202^{* * *}$ \\
& $(0.008)$ & $(0.008)$ & $(0.009)$ & $(0.062)$ & $(0.051)$ & $(0.045)$ \\
Female & $-0.135^{* * *}$ & $-0.164^{* * *}$ & $-0.178^{* * *}$ & $-0.210^{* * *}$ & $-0.304^{* * *}$ & $-0.414^{* * *}$ \\
& $(0.007)$ & $(0.008)$ & $(0.008)$ & $(0.058)$ & $(0.048)$ & $(0.044)$ \\
Other control variables & Yes & Yes & Yes & Yes & Yes & Yes \\
Observations & 12882 & 12882 & 12882 & 2855 & 4158 & 4897 \\
Adjusted $\mathrm{R}^{2}$ & 0.139 & 0.160 & 0.178 & 0.063 & 0.056 & 0.053 \\
\hline
\end{tabular}

Note: Reform is equal to one for the Treatment group and zero for the Comparison group. Besides gender all models include controls for age, children 0-6 years, married, country of birth, education, refugee category, days of national registration, month of residence permit, local unemployment in the outcome year and county in the outcome year. Robust standard errors in parentheses. ${ }^{* * *} p<0.01,{ }^{* *} p<0.05,{ }^{*} p<0.1$.

Table 4. Estimated effects of the Establishment Reform on A: the probability of any employment and B: on the logarithm of annual earnings in the third year after program start, 2014 vs. 2013.

\begin{tabular}{l|cc|cc}
\hline & \multicolumn{2}{|c|}{ A. Employment } & \multicolumn{2}{c}{ B. Earnings } \\
& Men & Women & Men & Women \\
\hline \multirow{2}{*}{ Reform } & $0.030^{* *}$ & $0.022^{*}$ & $0.148^{* * *}$ & $0.302^{* * *}$ \\
& $(0.013)$ & $(0.012)$ & $(0.055)$ & $(0.080)$ \\
Control variables & Yes & Yes & Yes & Yes \\
Observations & 6,552 & 6,330 & 3,182 & 1,715 \\
Adjusted $\mathrm{R}^{2}$ & 0.140 & 0.156 & 0.044 & 0.047 \\
\hline
\end{tabular}

Note: Reform is equal to one for the Treatment group and zero for the Comparison group. All models include controls for age, children 0-6 years, married, country of birth, education, refugee category, days of national registration, month of residence permit, local unemployment in the outcome year and county in the outcome year. Robust standard errors in parentheses. $* * * p<0.01, * * p<0.05, * p<0.1$. 
Table 5. Estimated change in probability of employment and in earnings from the first year after program start to the third year after program start separately for the Treatment and Comparison group. Both sexes.

\begin{tabular}{l|cc|cc}
\hline & \multicolumn{2}{|c|}{ Employment } & \multicolumn{2}{c}{ Earnings } \\
& $\begin{array}{c}\text { Treatment } \\
\text { group }\end{array}$ & $\begin{array}{c}\text { Comparison } \\
\text { group }\end{array}$ & $\begin{array}{c}\text { Treatment } \\
\text { group }\end{array}$ & $\begin{array}{c}\text { Comparison } \\
\text { group }\end{array}$ \\
\hline 1st year after prog. & Reference & Reference & Reference & Reference \\
start (2012/2011) & & & & \\
2nd year after prog. & $0.120^{* * *}$ & $0.108^{* * *}$ & $\mathbf{0 . 5 1 9 * * *}$ & $\mathbf{0 . 4 0 2 * * *}$ \\
start (2013/2012) & $(0.005)$ & $(0.005)$ & $\mathbf{( 0 . 0 4 2 )}$ & $\mathbf{( 0 . 0 4 6 )}$ \\
3rd year after prog. & $0.206^{* * *}$ & $0.163^{* * *}$ & $0.849 * * *$ & $0.663^{* * *}$ \\
start (2014/2013) & $(0.007)$ & $(0.007)$ & $(0.045)$ & $(0.051)$ \\
Control variables & Yes & Yes & Yes & Yes \\
Observations & 19,017 & 18,978 & 6,181 & 5,691 \\
Adjusted $\mathrm{R}^{2}$ & 0.224 & 0.206 & 0.121 & 0.118 \\
\hline
\end{tabular}

Note: Reform is equal to one for the Treatment group and zero for the Comparison group. Besides gender all models include controls for age, children 0-6 years, married, country of birth, education, refugee category, days of national registration, month of residence permit and municipality of residence in the outcome year. Estimates in italics are significantly different at $p<0.01$ and those in bold are significantly different at $p<0.1$. Robust standard errors in parentheses. $* * * p<0.01, * * p<0.05, * p<0.1$.

Table 6. Sensitivity analysis I. Estimated effects of a placebo reform on the probability of employment and on annual earnings. Both sexes.

\begin{tabular}{l|cc|cc}
\hline \multirow{2}{*}{ Reform } & \multicolumn{2}{|c|}{ Employment } & \multicolumn{2}{c}{ Earnings } \\
& $\begin{array}{l}\text { Our estimated } \\
\text { effect 2014/13 }\end{array}$ & $\begin{array}{c}\text { Placebo estimate } \\
\text { Our estimated }\end{array}$ & $\begin{array}{c}\text { Placebo estimate } \\
\text { effect 2014/13 }\end{array}$ & $2013 / 12$ \\
\hline \multirow{2}{*}{ Control variables } & $0.027^{* * *}$ & 0.009 & $0.202^{* * *}$ & 0.036 \\
Observations & $(0.009)$ & $(0.008)$ & $(0.045)$ & $(0.050)$ \\
Adjusted $\mathrm{R}^{2}$ & Yes & Yes & Yes & Yes \\
& 12,882 & 12,809 & 4,897 & 4,174 \\
\hline
\end{tabular}

Note: In the placebo estimations, reform is equal to one for those who entered the municipal Introduction programs in Jan 1 to Nov 30, 2010 and zero for those who entered such programs in 2009. All models include controls for gender, age, children 0-6 years, married, country of birth, education, refugee category, days of national registration, month of residence permit - not in the placebo models, local unemployment in the outcome year and county in the outcome year. Robust standard errors in parentheses. ${ }^{* *} p<0.01, * * p<0.05, * p<0.1$. 
Table 7. Sensitivity analysis II. Estimated effects on employment and earnings for those who entered the Establishment program in 2012 as compared to our Treatment group. Both sexes.

\begin{tabular}{l|cc}
\hline & $\begin{array}{c}\text { Employment } \\
\text { in 2013/2014 }\end{array}$ & $\begin{array}{c}\text { Earnings } \\
\text { In 2013/2014 }\end{array}$ \\
\hline Establishment plan in 2012 & $0.016^{* *}$ & 0.054 \\
& $(0.008)$ & $(0.042)$ \\
Control variables & Yes & Yes \\
Observations & 14676 & 5285 \\
Adjusted $R^{2}$ & 0.193 & 0.074 \\
\hline
\end{tabular}

Note: Establishment plan in 2012 takes the value one for those who entered the program in 2012 and zero for those who entered one year earlier. All models include controls for gender, age, children 0-6 years, married, country of birth, education, refugee category, days of national registration, month of residence permit, local unemployment in the outcome year and county in the outcome year. Robust standard errors in parentheses. ${ }^{* * *} p<0.01,{ }^{* *} p<0.05,{ }^{*} p<0.1$. 


\section{Appendix}

Table A. Estimated effects of the Establishment Reform on the probability of any employment in 2014 (Treatment group) and 2013 (Comparison group). Both sexes.

\begin{tabular}{|c|c|c|c|c|}
\hline & I & II & III & IV \\
\hline Reform & $\begin{array}{c}0.057^{* * *} \\
(0.009)\end{array}$ & $\begin{array}{c}0.065^{* * *} \\
(0.008)\end{array}$ & $\begin{array}{c}0.037^{* * *} \\
(0.008)\end{array}$ & $\begin{array}{c}0.027^{* * *} \\
(0.009)\end{array}$ \\
\hline Female & & $\begin{array}{c}-0.214^{* * *} \\
(0.008)\end{array}$ & $\begin{array}{c}-0.212^{* * *} \\
(0.008)\end{array}$ & $\begin{array}{c}-0.178^{* * *} \\
(0.008)\end{array}$ \\
\hline Age & & $\begin{array}{c}-0.009 * * * \\
(0.000)\end{array}$ & $\begin{array}{c}-0.010 * * * \\
(0.000)\end{array}$ & $\begin{array}{c}-0.009 * * * \\
(0.000)\end{array}$ \\
\hline Children under 7 & & $\begin{array}{c}-0.116^{* * *} \\
(0.009)\end{array}$ & $\begin{array}{c}-0.124 * * * \\
(0.009)\end{array}$ & $\begin{array}{c}-0.111^{* * *} \\
(0.009)\end{array}$ \\
\hline Married & & $\begin{array}{c}-0.040 * * * \\
(0.009)\end{array}$ & $\begin{array}{l}-0.015^{*} \\
(0.009)\end{array}$ & $\begin{array}{l}-0.003 \\
(0.009)\end{array}$ \\
\hline \multicolumn{5}{|l|}{ Country of birth } \\
\hline Afghanistan & & & $\begin{array}{c}0.078 * * * \\
(0.018)\end{array}$ & $\begin{array}{c}0.108 * * * \\
(0.019)\end{array}$ \\
\hline Eritrea & & & $\begin{array}{c}0.175^{* * *} \\
(0.016)\end{array}$ & $\begin{array}{c}0.131^{* * *} \\
(0.017)\end{array}$ \\
\hline Europe & & & $\begin{array}{c}0.158^{* * *} \\
(0.028)\end{array}$ & $\begin{array}{c}0.129 * * * \\
(0.028)\end{array}$ \\
\hline Iraq & & & $\begin{array}{c}\text { Reference } \\
-\end{array}$ & $\begin{array}{c}\text { Reference } \\
-\end{array}$ \\
\hline Iran & & & $\begin{array}{c}0.144^{* * *} \\
(0.020)\end{array}$ & $\begin{array}{c}0.082^{* * *} \\
(0.021)\end{array}$ \\
\hline Somalia & & & $\begin{array}{l}-0.009 \\
(0.012)\end{array}$ & $\begin{array}{c}0.034^{* *} \\
(0.013)\end{array}$ \\
\hline Other African country & & & $\begin{array}{c}0.153^{* * *} \\
(0.019)\end{array}$ & $\begin{array}{c}0.128^{* * *} \\
(0.019)\end{array}$ \\
\hline Other Asian country & & & $\begin{array}{c}0.219 * * * \\
(0.022)\end{array}$ & $\begin{array}{c}0.140 * * * \\
(0.022)\end{array}$ \\
\hline Other Middle-East & & & $\begin{array}{c}0.087^{* * *} \\
(0.020)\end{array}$ & $\begin{array}{c}0.084^{* * *} \\
(0.021)\end{array}$ \\
\hline Other regions & & & $\begin{array}{c}0.169 * * * \\
(0.053)\end{array}$ & $\begin{array}{c}0.105^{* *} \\
(0.050)\end{array}$ \\
\hline \multicolumn{5}{|l|}{ Education } \\
\hline Primary $<9$ years & & & & Reference \\
\hline Lower Secondary & & & & $\begin{array}{c}0.066 * * * \\
(0.016)\end{array}$ \\
\hline Upper Secondary & & & & $\begin{array}{c}0.127^{* * *} \\
(0.011)\end{array}$ \\
\hline Post Secondary & & & & $\begin{array}{c}0.154^{* * *} \\
(0.012)\end{array}$ \\
\hline Unknown & & & & $\begin{array}{c}-0.093 * * * \\
(0.014)\end{array}$ \\
\hline
\end{tabular}


Table A (cont.)

\section{Refugee Category}

Own Housing

Reference.

Quota Refugee

SMB Housing

Family Reunion

$-0.067^{* * *}$

(0.014)

0.010

(0.007)

Recidence permit

Month 1 - 3

Reference

Month 4 - 6

$-0.002$

(0.012)

$-0.018$

Month 7 - 9

(0.017)

$-0.023$

(0.022)

Local Unemployment Rate

County

Yes

\begin{tabular}{lcccc} 
Constant & $0.360^{* * *}$ & $0.848^{* * *}$ & $0.818^{* * *}$ & $0.735^{* * *}$ \\
& $(0.006)$ & $(0.016)$ & $(0.020)$ & $(0.104)$ \\
\hline Observations & 12,882 & 12,882 & 12,882 & 12,882 \\
Adjusted $\mathrm{R}^{2}$ & 0.003 & 0.104 & 0.128 & 0.178 \\
\hline
\end{tabular}

Note: Reform is equal to one for the Treatment group and zero for the Comparison group.. Robust standard errors in parentheses. ${ }^{* * *} p<0.01,{ }^{* *} p<0.05,{ }^{*} p<0.1$ 
Table B. Estimated effects of the Establishment Reform on the logarithm of the annual earnings in 2014 (Treatment group) and 2013 (Comparison group). Both sexes.

\begin{tabular}{|c|c|c|c|c|}
\hline & I & II & III & IV \\
\hline Reform & $\begin{array}{c}0.190 * * * \\
(0.041)\end{array}$ & $\begin{array}{c}0.196 * * * \\
(0.041)\end{array}$ & $\begin{array}{c}0.152^{* * *} \\
(0.042)\end{array}$ & $\begin{array}{c}0.202^{* * *} \\
(0.045)\end{array}$ \\
\hline Female & & $\begin{array}{c}-0.393^{* * *} \\
(0.044)\end{array}$ & $\begin{array}{c}-0.407^{* * *} \\
(0.044)\end{array}$ & $\begin{array}{c}-0.414 * * * \\
(0.044)\end{array}$ \\
\hline Age & & $\begin{array}{c}0.003 \\
(0.003)\end{array}$ & $\begin{array}{c}-0.001 \\
(0.003)\end{array}$ & $\begin{array}{l}-0.000 \\
(0.003)\end{array}$ \\
\hline Children under 7 & & $\begin{array}{c}-0.127^{* * *} \\
(0.048)\end{array}$ & $\begin{array}{c}-0.152^{* * *} \\
(0.049)\end{array}$ & $\begin{array}{c}-0.110^{* *} \\
(0.049)\end{array}$ \\
\hline Married & & $\begin{array}{c}0.030 \\
(0.045)\end{array}$ & $\begin{array}{l}0.079 * \\
(0.046)\end{array}$ & $\begin{array}{c}0.095 * * \\
(0.046)\end{array}$ \\
\hline Country of birth & & & & \\
\hline Afghanistan & & & $\begin{array}{c}-0.211^{* *} \\
(0.101)\end{array}$ & $\begin{array}{l}-0.112 \\
(0.103)\end{array}$ \\
\hline Eritrea & & & $\begin{array}{c}0.098 \\
(0.075)\end{array}$ & $\begin{array}{c}0.116 \\
(0.082)\end{array}$ \\
\hline Europe & & & $\begin{array}{c}0.269 * * \\
(0.131)\end{array}$ & $\begin{array}{c}0.319 * * \\
(0.132)\end{array}$ \\
\hline Iraq & & & $\begin{array}{c}\text { Reference } \\
-\end{array}$ & $\begin{array}{c}\text { Reference } \\
-\end{array}$ \\
\hline Iran & & & $\begin{array}{l}-0.018 \\
(0.094)\end{array}$ & $\begin{array}{c}-0.025 \\
(0.098)\end{array}$ \\
\hline Somalia & & & $\begin{array}{c}-0.232 * * * \\
(0.069)\end{array}$ & $\begin{array}{c}-0.164^{* *} \\
(0.076)\end{array}$ \\
\hline Other African country & & & $\begin{array}{l}-0.111 \\
(0.090)\end{array}$ & $\begin{array}{l}-0.029 \\
(0.092)\end{array}$ \\
\hline Other Asian country & & & $\begin{array}{c}0.032 \\
(0.103)\end{array}$ & $\begin{array}{c}0.018 \\
(0.104)\end{array}$ \\
\hline Other Middle-East & & & $\begin{array}{l}-0.025 \\
(0.105)\end{array}$ & $\begin{array}{c}0.045 \\
(0.105)\end{array}$ \\
\hline Other regions & & & $\begin{array}{c}0.182 \\
(0.282)\end{array}$ & $\begin{array}{c}0.127 \\
(0.275)\end{array}$ \\
\hline Education & & & & \\
\hline Primary $<9$ years & & & & $\begin{array}{c}\text { Reference } \\
-\end{array}$ \\
\hline Lower Secondary & & & & $\begin{array}{l}-0.066 \\
(0.081)\end{array}$ \\
\hline Upper Secondary & & & & $\begin{array}{c}0.047 \\
(0.053)\end{array}$ \\
\hline Post Secondary & & & & $\begin{array}{c}0.063 \\
(0.059)\end{array}$ \\
\hline Unknown & & & & $\begin{array}{c}0.356^{* *} \\
(0.141)\end{array}$ \\
\hline
\end{tabular}


Table B (cont.)

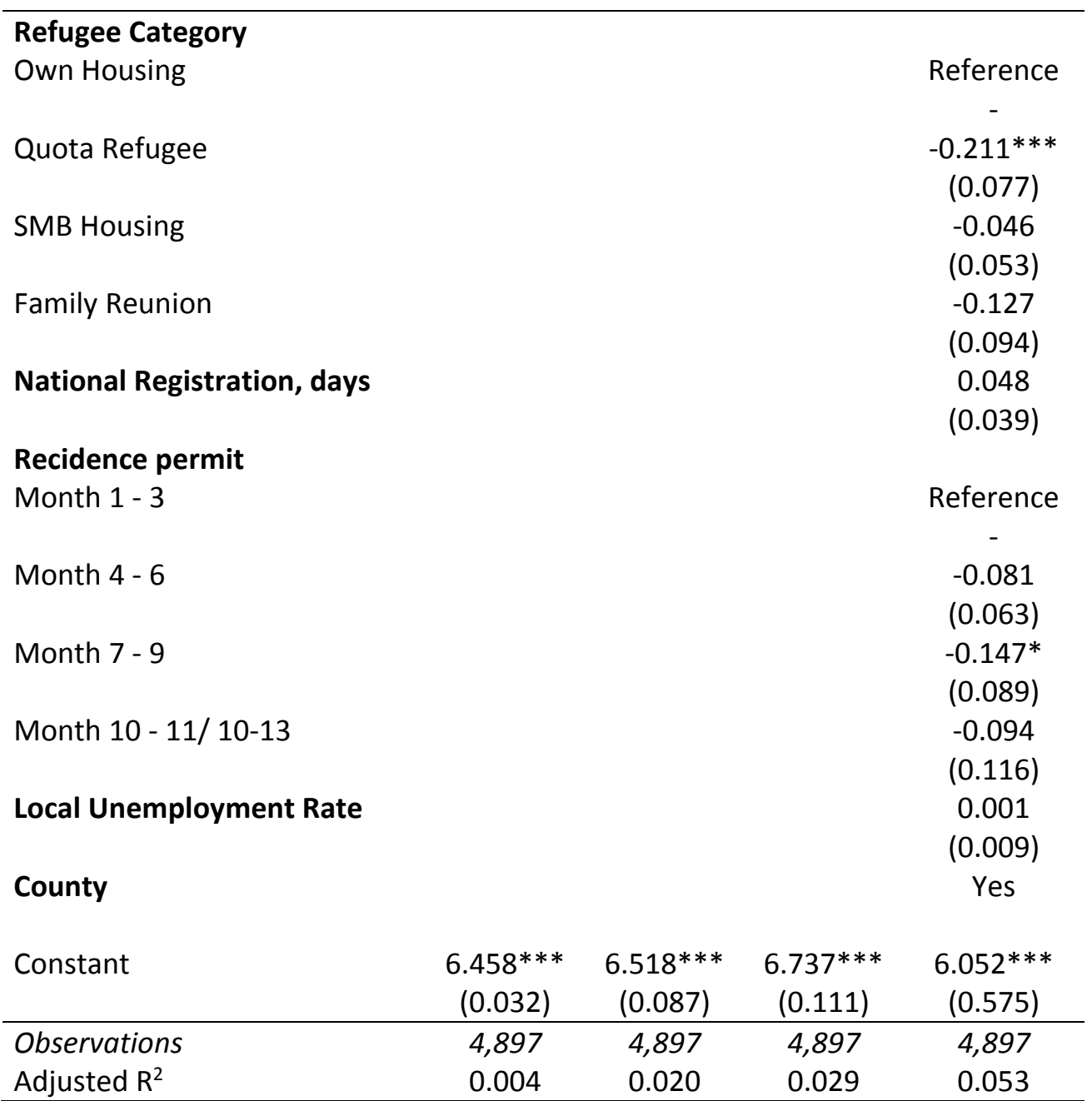

Note: Reform is equal to one for the Treatment group and zero for the Comparison group. Robust standard errors in parentheses. ${ }^{* * *} p<0.01,{ }^{* *} p<0.05,{ }^{*} p<0.1$ 